\title{
DAMPAK KEBIJAKAN SUKU BUNGA SBI TERHADAP PROFITABILITAS PERBANKAN (STUDI KASUS BPR KONVENSIONAL DENGAN BPR SYARIAH DI KOTA BATAM)
}

\author{
Erni Yanti Natalia ${ }^{1}$, Sri Afridola ${ }^{2}$. \\ Dosen Universitas Putera Batam. \\ email: erni.siallagan@gmail.com
}

\begin{abstract}
The phenomenon of BPR growth in Batam City has not been accompanied by credit growth. In fact, this credit is a source of income in the banking world. The more credit that can be distributed to the public, the greater the profit that will be obtained and the level of profitability that will be obtained. The purpose of this study is to determine whether there is an influence of the SBI Interest Rate on Profitability (ROA) in conventional BPR and Sharia BPR in Batam City, as well as to compare the ROA performance between the two BPRs. Data were analyzed using Statistical Product and Service Solution (SPSS) software version 20. The results of the study using the t test showed that the SBI Interest Rate did not affect the Profitability (ROA) of Conventional Rural Banks in Batam City with a significance value (Sig) $0.791<0,05$, SBI Interest Rates do not affect the Profitability (ROA) of Sharia Rural Banks in Batam City with a significance value (Sig) $0.385<0.05$. Whereas by using the different $t$-test, it was found that there was a difference in the performance of Profitability (ROA) on Conventional Rural Banks and Sharia Rural Banks Sig. (2-tailed) of 0,000 <0.05.
\end{abstract}

Keywords: SBI Interest Rates; Profitability; ROA; BPR Conventional; BPR Syariah.

\section{PENDAHULUAN}

Di Indonesia, Usaha Mikro Kecil dan Menengah (UMKM) memberikan kontribusi penting bagi pertumbuhan ekonomi dan penciptaan lapangan kerja. UMKM mampu menyumbang 57\% Pendapatan Domestik Bruto (PDB) dan menyerap 60\% tenaga kerja. Undang-undang No.20 tahun 2008 tentang UMKM, mengamanatkan kepada Pemerintah dan Pemerintah Daerah untuk menumbuhkan iklim usaha dengan menetapkan kebijakan terkait pendanaan. Kebijakan pendanaan tersebut ditujukan untuk memperluas sumber pendanaan dan memfasilitasi UMKM pada kredit bank/nonbank, membantu UMKM mendapatkan pembiayaan dan jasa/produk keuangan lainnya dengan jaminan pemerintah. Sejalan dengan amanat UU tersebut, Pemerintah meluncurkan Kredit Usaha Rakyat (KUR) tahun 2007.(Widiyanti, 2018) KUR membantu UMKM memperoleh tambahan modal agar usaha mereka bisa bertumbuh dan berkembang, sehingga keterbatasan modal dapat diatasi.

Suku bunga KUR pertama kali (2007) sebesar 22\% dan sampai 1 Januari 2018 bunga KUR telah diturunkan menjadi $7 \%$. Selain menurunkan suku bunga KUR, kebijakan lain yang dilakukan pemerintah adalah menurunkan BI Rate (suku bunga acuan). Berikut ini gambar penurunan BI Rate 2014-2016: 


\begin{tabular}{|c|c|c|}
\hline Tanggal & Bl Rate & Siaran Pers \\
\hline 21 Juli 2016 & $6.50 \%$ & Pranala Siaran Pers \\
\hline 16 Junl 2016 & $6.50 \%$ & Pranala Slaran Pers \\
\hline 19 Mei 2016 & $6.75 \%$ & Pranala Siaran Pers \\
\hline 21 April 2016 & $6.75 \%$ & Pranala Siaran Pers \\
\hline 17 Maret 2016 & $6.75 \%$ & Pranala Siaran Pers \\
\hline 18 Februari 2016 & $7.00 \%$ & Pranala Siaran Pers \\
\hline 14 Januari 2016 & $7.25 \%$ & Pranala Siaran Pers \\
\hline 17 Desember 2015 & $7.50 \%$ & Pranala Siaran Pers \\
\hline 17 Nopember 2015 & $7.50 \%$ & Pranala Siaran Pers \\
\hline 15 Oktober 2015 & $7.50 \%$ & Pranala Siaran Pers \\
\hline 17 September 2015 & $7.50 \%$ & Pranala Siaran Pers \\
\hline 18 Agustus 2015 & $7.50 \%$ & Pranala Siaran Pers \\
\hline 14 Juli 2015 & $7.50 \%$ & Pranala Siaran Pers \\
\hline 18 Juni 2015 & $7.50 \%$ & Pranala Siaran Pers \\
\hline 19 Mei 2015 & $7.50 \%$ & Pranala Siaran Pers \\
\hline 14 April 2015 & $7.50 \%$ & Pranala Siaran Pers \\
\hline 17 Maret 2015 & $7.50 \%$ & Pranala Siaran Pers \\
\hline 17 Februari 2015 & $7.50 \%$ & Pranala Siaran Pers \\
\hline 15 Januari 2015 & $7.75 \%$ & Pranala Siaran Pers \\
\hline 11 Desember 2014 & $7.75 \%$ & Pranala Siaran Pers \\
\hline 18 Nopombor 2014 & $7.75 \%$ & Pranala Siaran Ners \\
\hline 13 Nopember 2014 & $7.50 \%$ & Pranala Siaran Pers \\
\hline 7 Oktober 2014 & $7.50 \%$ & Pranala Siaran Pers \\
\hline 11 September 2014 & $7.50 \%$ & Pranala Siaran Pers \\
\hline 14 Agustus 2014 & $7.50 \%$ & Pranala Siaran Pers \\
\hline
\end{tabular}

Gambar 1. BI Rate

Dari gambar diatas terlihat bahwa Agustus 2014 BI Rate sebesar 7,50\% dan mengalami kenaikan sebesar 7,75\% pada Nopember 2014. Sejak Februari 2015, BI Rate mengalami penurunan menjadi 6,50\% (Juli 2016). Pada Desember 2017 BI Rate sebesar 4,75\% dan per 19 Februari 2018 Bank Indonesia (BI) telah berhasil mempertahankan BI Rate sebesar 4,25\%.(Embu, 2018) Ada empat alasan pemerintah menurunkan BI rate, yaitu: a) inflasi hingga pertengahan 2017 lebih rendah dari perkiraan sebelumnya; b) defisit transaksi berjalan (current account deficit/CAD) tetap terkendali; c) faktor risiko eksternal mereda (kebijakan bank sentral AS); d) penurunan suku bunga acuan diharapkan dapat mendorong penyaluran kredit perbankan sekaligus mendukung pertumbuhan ekonomi secara berkelanjutan. Tetapi, pertumbuhan kredit per Juni 2017 sebesar 7,8\% secara tahunan. Angka ini lebih rendah dibandingkan sebelumnya yang tercatat sebesar $8,7 \%$.(Natalia, n.d.)

Kota Batam merupakan sarangnya pertumbuhan Bank Perkreditan Rakyat (BPR), perkembangannya mengalahkan Bank Umum. Seharusnya menjamurnya BPR akan memberikan kontribusi bagi perekonomian KEPRI. Kenyataannya hingga Triwulan III-2017, pertumbuhan ekonomi KEPRI berada di posisi paling rendah nasional dan Sumatera.(Putra, 2017) Berdasarkan data Otoritas Jasa Keuangan (www.ojk.go.id), terdapat 27 BPR yang terdaftar di Kota Batam. Dari total tersebut, 24 diantaranya adalah BPR Konvensional dan 3 diantaranya adalah BPR Syariah.

Fenomena pertumbuhan BPR tersebut belum dibarengi dengan pertumbuhan kredit. Pertumbuhan kredit belum sesuai harapan, padahal kredit merupakan penjualan (sumber pendapatan) dalam dunia perbankan. Semakin banyak kredit yang dapat disalurkan ke masyarakat, maka semakin besar pula laba yang akan didapatkan dan tingkat profitabilitas yang akan diperoleh. Gambar 2 berikut terlihat bahwa terdapat 12 BPR di Kota Batam mengalami penurunan "Jumlah Kredit Yang Diberikan" dan profitabilitas (ROA) dari tahun 2016 ke 2017. Selain mengalami penurunan, salah satu BPR (BPR Ukabima) bahkan menunjukkan kinerja ROA yang negatif. 


\begin{tabular}{|c|l|r|r|r|r|}
\hline \multirow{2}{*}{ NO } & \multirow{2}{*}{ NAMA BANK } & \multicolumn{2}{c|}{$\begin{array}{c}\text { Jumlah Kredit yang } \\
\text { Diberikan }\end{array}$} & \multicolumn{2}{|c|}{ ROA } \\
\cline { 3 - 6 } & & $\begin{array}{c}\text { Desember } \\
\mathbf{2 0 1 6}\end{array}$ & $\begin{array}{c}\text { Desember } \\
\mathbf{2 0 1 7}\end{array}$ & $\begin{array}{c}\text { Desember } \\
\mathbf{2 0 1 6}\end{array}$ & $\begin{array}{c}\text { Desember } \\
\mathbf{2 0 1 7}\end{array}$ \\
\hline 1 & & $171,985,992$ & $159,858,624$ & 3 & 3 \\
\hline 2 & BPR BANDA RAYA & $157,094,837$ & $156,271,916$ & 2 & 0 \\
\hline 3 & BPR CENTRAL KEPRI & $61,896,757$ & $53,632,530$ & 4 & 5 \\
\hline 4 & BPR DANA MAKMUR & $50,405,053$ & $46,483,433$ & 5 & 4 \\
\hline 5 & BPR DANA NAGOYA & $125,544,438$ & $117,757,699$ & 3 & 2 \\
\hline 6 & BPR INDOBARU & $137,027,030$ & $121,182,365$ & 5 & 3 \\
\hline 7 & BPR KEPRI BATAM & $91,698,789$ & $82,568,355$ & 5 & 5 \\
\hline 8 & BPR KINTAMAS & $119,179,442$ & $107,998,107$ & 4 & 1 \\
\hline 9 & BPR MAJESTY & $101,220,668$ & $87,223,374$ & 5 & 4 \\
\hline 10 & BPR PUNDI MASYARAKAT & $20,261,912$ & $18,561,257$ & 4 & 4 \\
\hline 11 & BPR SATYA & $58,384,626$ & $52,540,590$ & 0 & 1 \\
\hline 12 & BPR UKABIMA & $11,820,841$ & $10,691,287$ & -10 & 0 \\
\hline
\end{tabular}

Gambar 2. Kredit dan ROA

Sementara itu, pada tahun 2016-2018 BI Rate mengalami penurunan secara terus menerus dan signifikan. Penurunan suku bunga acuan seharusnya akan menambah nilai kompetitif antar kedua jenis bank. Kenyataannya, nilai profitabilitas masih menunjukkan penurunan beberapa BPR di Kota Batam. Untuk itu peneliti tertarik untuk melakukan penelitian, apakah kebijakan suku bunga SBI memberikan pengaruh yang signifikan terhadap BPR Konvensional dan BPR Syariah yang ada di Kota Batam.

\section{TINJAUAN PUSTAKA}

\section{Suku Bunga SBI}

Menurut Hasibuan, bunga merupakan hal penting bagi suatu bank dalam penarikan tabungan dan penyaluran kreditnya. Bunga bagi bank bisa menjadi biaya (cost of fund) yang harus dibayarkan kepada penabung. Tetapi di lain pihak, bunga juga dapat merupakan pendapatan bank yang diterima dari debitor karena kredit yang diberikannya. Dalam perekonomian modern, penggunaan bunga senantiasa dikaitkan dengan operasionalisasi sistem perbankan dengan bunga sebagai instrumen utamanya. Kebijakan tingkat suku bunga merupakan kebijakan moneter yang diputuskan oleh pemerintah untuk mendorong pertumbuhan ekonomi perbankan. Di Indonesia, informasi mengenai kebijakan moneter dapat dipantau melalui suku bunga Sertifikat Bank Indonesia (SBI). Suku Bunga SBI adalah tingkat bunga SBI tahunan yang dikeluarkan tiap bulan. Tingkat bunga ini diharapkan dapat mewakili tingkat bunga secara umum, karena kenyataannya tingkat bunga yang berlaku di pasar, fluktuasinya mengikuti SBI.(Puspitasari, 2009)

\section{Profitabilitas}

Menurut Kasmir, profitabilitas merupakan rasio untuk menilai kemampuan perusahaan dalam mencari keuntungan. Rasio ini juga memberikan ukuran tingkat efektivitas manajemen suatu perusahaan. Hal ini ditunjukkan oleh laba yang dihasilkan dari penjualan dan pendapatan investasi. Profitabilitas merupakan rasio yang menggambarkan kemampuan perusahaan dalam menghasilkan laba melalui semua kemampuan dan sumber daya yang dimilikinya, yaitu yang bersal dari kegiatan penjualan, penggunaan aset, maupun penggunaan modal. dari aktivitas normal bisnisnya. Pengukuran rasio profitabilias dapat dilakukan dengan membandingan berbagai komponen yang ada di dalam laporan laba rugi dan/atau neraca. Pengukuran dapat dilakukan untuk beberapa periode. Dengan melakukan analisis rasio keuangan secara berskala memungkinkan bagi manajemen untuk secara efektif menetapkan langkah-langkah target yang telah ditetapkan sebelumnya atau bisa juga dibandingkan dengan standar rasio rata-rata industri (Kasmir, 2015). Jenis- jenis rasio profitabilitas yang lazim digunakan adalah sebagi berikut: 
1. Return On Asset (Hasil Pengembalian atas Aset)

2. Return On Equity (Hasil Pengembalian atas Ekuitas)

3. Gross Profit Margin (Marjin Laba Kotor)

4. Operating Profit Margin (Marjin Laba Operasional)

5. Net Profit Margin (Marjin Laba Bersih )

\section{Return On Assets (ROA)}

Menurut Sofyan, Return On Assets (ROA) adalah rasio yang digunakan untuk mengukur kemampuan manajemen Bank dalam memperoleh keuntungan secara keseluruhan. Semakin besar ROA, semakin besar pula tingkat laba yang akan dicapai bank tersebut dan semakin baik pula posisi bank dari segi penggunaan aset. Rasio ini menggambarkan perputaran aktiva diukur dari volume penjualan. Semakin besar rasio ini semakin baik. Hal ini berarti bahwa aktiva dapat lebih cepat berputar dan meraih laba. (Natalia, 2017)

Rumus yang digunakan untuk mencari ROA adalah sebagai berikut:

\section{Hipotesis Penelitian}

$\mathrm{ROA}=\frac{\text { Laba Bersih }}{\text { Total Aktiva }} \quad$ Rumus 2 Return On Asset

Adapun hipotesis penelitian ini adalah sebagai berikut:

H1 : Ada pengaruh Suku Bunga SBI terhadap Profitabilitas (ROA) pada BPR Konvensional Di Kota Batam.

H2 : Ada pengaruh Suku Bunga SBI terhadap Profitabilitas (ROA) pada BPR Syariah Di Kota Batam.

H3 : Ada perbedaan kinerja Profitabilitas (ROA) pada BPR Konvensional dan BPR Syariah Di Kota Batam.

\section{METODE}

\section{Populasi dan Sampel}

Populasi adalah sekumpulan individu yang memiliki karakterisitk khas yang menjadi perhatian dalam lingkup yang diteliti. Sampel adalah sebagian dari anggota populasi yang diambil menurut prosedur tertentu. (Sugiarto, 2017). Berdasarkan data yang diperoleh dari laman Otoritas Jasa Keuangan (OJK, 2018) terdapat 27 BPR Konvensional dan 2 BPR Syariah di Kota Batam. Teknik pengambilan sampel dalam penelitian ini menggunakan non-probability sampling, dengan metode purposive sampling dimana pengambilan sampel dilakukan dengan berdasarkan kriteria sebagai berikut:

1. Data yang akan dianalisis yaitu pada periode triwulan dari tahun 2015-2018.

2. Data BPR Konvensional dan BPR Syariah yang akan dianalisis diambil masing-masing sebanyak 2 BPR.

3. BPR Konvensional dipilih secara random dengan bantuan situs www.random.org dan yang terpilih BPR Agra Dhana dan BPR Majesty Golden Raya.

4. BPR Syariah dipilih sebanyak jumlah yang ada karena hanya ada 2 BPR Syariah Di Kota Batam yaitu adalah BPRS Vitka Central dan BPRS Syarikat Madani.

5. Data yang diambil untuk diolah hanya yang bernilai tidak nol dan tidak ekstrim.

\section{Teknik Analisis Data}

Adapun teknik analisis data yang digunakan dalam penelitian ini adalah sebagai berikut:

1. Statistik Deskriptif. Statistik deskriptif bertujuan untuk memberikan informasi mengenai karakteristik penelitian yang utama. Ukuran yang digunakan dalam deskripsi antara lain berupa frekuensi, tendensi sentral (mean, median, modus), dispersi (deviasi standard dan varian) dan koefisien korelasi antar variabel penelitian.

2. Uji Asumsi Klasik. Uji ini digunakan sebagai syarat-syarat yang harus dipenuhi pada model regresi agar model tersebut valid sebagai alat penduga.

3. Uji Hipotesis. Uji hipotesis dilakukan untuk model regresi sederhana dan uji beda dua sampel yang tidak berpasangan dengan menggunakan Beda Independen T-test. Uji beda t-test digunakan untuk menentukan apakah dua sample yang tidak berhubungan memiliki nilai rata-rata yang berbeda. Uji beda t-test dilakukan dengan cara 
membandingkan perbedaan antara dua nilai rata-rata dengan standar error dari perbedaan rata-rata dua sample.(Ghozali, 2016). Secara rumus dapat ditulis sebagai berikut:

T Test $=\underline{\text { Rata-rata sampel pertama }- \text { Rata-rata sampel kedua }}$

Rumus 3. Uji T-test

Standar error perbedaan rata-rata kedua sampel

Standar error perbedaan dalam nilai rata-rata terdistribusi secara normal. Jadi tujuan uji t-test adalah membandingkan rata-rata dua grup yang tidak berhubungan satu dengan yang lain. Apakah kedua grup tersebut memiliki nilai rata-rata yang sama ataukah tidak sama secara signifikan.(Ghozali, 2016)

\section{HASIL DAN PEMBAHASAN}

\section{Uji Asumsi Klasik BPR Konvensional}

\section{Uji Normalitas BPR Konvensional}

Berikut ini adalah hasil uji normalitas data BPR Konvensional (BPR) yang ada di Kota Batam untuk variabel Suku Bunga SBI dan ROA.

Tabel 1. Uji Normalitas Suku Bunga SBI

One-Sample Kolmogorov-Smirnov Test

\begin{tabular}{|ll|r|}
\hline & & \multicolumn{1}{|c|}{$\begin{array}{c}\text { Suku Bunga } \\
\text { SBI }\end{array}$} \\
\hline N & Mean & 28 \\
Normal Parameters ${ }^{\mathrm{a}, \mathrm{b}}$ & Std. Deviation & 6.1614 \\
& Absolute & .69553 \\
Most Extreme Differences & Positive & .170 \\
& Negative & .170 \\
Kolmogorov-Smirnov Z & & -.164 \\
Asymp. Sig. (2-tailed) & & .898 \\
\hline
\end{tabular}

a. Test distribution is Normal.

b. Calculated from data.

Sumber: Hasil Olah SPSS 20

Tabel 2. Uji Normalitas ROA BPR

One-Sample Kolmogorov-Smirnov Test

\begin{tabular}{|ll|r|}
\hline N & ROA_BPR \\
Normal Parameters ${ }^{\mathrm{a}, \mathrm{b}}$ & Mean & 28 \\
& Std. Deviation & 3.0714 \\
& Absolute & 1.41234 \\
Most Extreme Differences & Positive & .209 \\
& Negative & .169 \\
Kolmogorov-Smirnov Z & & -.209 \\
Asymp. Sig. (2-tailed) & & 1.105 \\
& & .174 \\
\hline
\end{tabular}

a. Test distribution is Normal.

b. Calculated from data.

Sumber: Hasil Olah SPSS 20

Berdasarkan tabel uji normalitas K-S diatas dapat disimpulkan bahwa data dalam penelitian ini berdistribusi normal karena nilai signifikansi (Sig) lebih besar dari 0,05. Untuk variabel ROA Konvensional (ROA_BPR) diperoleh nilai signifikan 0,174 > 0,05 sedangkan variabel Suku Bunga SBI 0,395 > 0,05.

Uji Linearitas BPR Konvensional

Berikut ini adalah hasil uji linearitas pada BPR Konvensional: 
Tabel 3. Uji Linearitas BPR Konvensional ANOVA Table

\begin{tabular}{|c|c|c|c|c|c|c|c|}
\hline & & & $\begin{array}{l}\text { Sum of } \\
\text { Squares }\end{array}$ & $\mathrm{df}$ & $\begin{array}{l}\text { Mean } \\
\text { Square }\end{array}$ & $\mathrm{F}$ & Sig. \\
\hline \multirow{5}{*}{$\begin{array}{l}\text { ROA_BPR * Suku } \\
\text { Bunga SBI }\end{array}$} & \multirow{3}{*}{$\begin{array}{l}\text { Between } \\
\text { Groups }\end{array}$} & (Combined) & 10.857 & 12 & \multirow{5}{*}{$\begin{array}{r}.905 \\
.149 \\
.974 \\
2.867\end{array}$} & \multirow{5}{*}{$\begin{array}{l}.316 \\
.052 \\
.340\end{array}$} & \multirow{5}{*}{$\begin{array}{l}.975 \\
.823 \\
.962\end{array}$} \\
\hline & & Linearity & .149 & 1 & & & \\
\hline & & Deviation from Linearity & 10.709 & 11 & & & \\
\hline & \multicolumn{2}{|c|}{ Within Groups } & 43.000 & 15 & & & \\
\hline & \multicolumn{2}{|l|}{ Total } & 53.857 & 27 & & & \\
\hline
\end{tabular}

Sumber: Hasil Olah SPSS 20

Berdasarkan nilai Signifikansi dalam tabel diatas dapat disimpulkan bahwa terdapat hubungan linear secara signifikan antara Suku Bunga SBI dengan ROA BPR Konvensional dengan nilai signifikan 0,962 lebih besar dari 0,05 .

\section{Uji Heterokedastisitas BPR Konvensional}

Berikut ini adalah hasil uji heterokedastisitas pada BPR Konvensional:

Tabel 4. Uji Heterokedastisitas BPR Konvensional Coefficients $^{\mathrm{a}}$

\begin{tabular}{|rl|r|r|r|r|r|}
\hline \multicolumn{2}{|l|}{ Model } & \multicolumn{2}{|c|}{ Unstandardized Coefficients } & \multicolumn{1}{|c|}{$\begin{array}{c}\text { Standardized } \\
\text { Coefficients }\end{array}$} & \multirow{2}{*}{ Sig. } \\
\cline { 3 - 5 } & \multicolumn{1}{|c|}{$\mathrm{B}$} & Std. Error & \multicolumn{1}{c|}{ Beta } & & \\
\hline \multirow{2}{*}{1} & (Constant) & 2.744 & 1.152 & & 2.382 & .025 \\
& Suku Bunga SBI & -.249 & .186 & -.254 & -1.338 & .193 \\
\hline
\end{tabular}

a. Dependent Variable: Abs_RES

Sumber: Hasil Olah SPSS 20

Hasil uji heteroskedastisitas dilakukan dengan Uji Glejser. Berdasarkan tabel diatas diperoleh Suku Bunga SBI nilai Sig sebesar 0,193 diatas 0,05 sehingga dapat disimpulkan bahwa tidak terjadi gejala heteroskedastisitas dalam model regresi ini.

\section{Uji Asumsi Klasik BPR Syariah}

\section{Uji Normalitas BPR Syariah}

Berikut ini adalah hasil uji normalitas data BPR Syariah (BPRS) yang ada Di Kota Batam untuk variabel Suku Bunga SBI dan ROA.

Tabel 5. Uji Normalitas Suku Bunga SBI

One-Sample Kolmogorov-Smirnov Test

\begin{tabular}{|ll|r|}
\hline & & \multicolumn{1}{|c|}{ Suku Bunga } \\
\hline $\mathrm{N}$ & SBI \\
Normal Parameters ${ }^{\mathrm{a}, \mathrm{b}}$ & Mean & 23 \\
& Std. Deviation & 6.1891 \\
& Absolute & .68221 \\
Most Extreme Differences & Positive & .205 \\
& Negative & .157 \\
Kolmogorov-Smirnov Z & & -.205 \\
Asymp. Sig. (2-tailed) & & .982 \\
\hline
\end{tabular}

a. Test distribution is Normal.

b. Calculated from data.

Sumber: Hasil Olah SPSS 20 
Tabel 6. Uji Normalitas ROA BPRS

One-Sample Kolmogorov-Smirnov Test

\begin{tabular}{|ll|r|}
\hline & & ROA \\
\hline N & & 23 \\
Normal Parameters & a,b & Mean \\
& Std. Deviation & 1.3478 \\
& Absolute & 1.72175 \\
Most Extreme Differences & .222 \\
& Positive & .222 \\
Kolmogorov-Smirnov Z & Negative & -.203 \\
Asymp. Sig. (2-tailed) & & 1.065 \\
\hline
\end{tabular}

a. Test distribution is Normal.

b. Calculated from data.

Sumber: Hasil Olah SPSS 20

Berdasarkan tabel uji normalitas K-S diatas dapat disimpulkan bahwa data dalam penelitian ini berdistribusi normal karena nilai signifikansi (Sig) lebih besar dari 0,05. Untuk variabel ROA BPR Syariah (ROA_BPRS) diperoleh nilai signifikan 0,207 > 0,05 sedangkan variabel Suku Bunga SBI 0,290 > 0,05.

\section{Uji Linearitas BPR Syariah}

Berikut ini adalah hasil uji linearitas pada BPR Syariah:

Tabel 7. Uji Linearitas BPR Syariah

ANOVA Table

\begin{tabular}{|c|c|c|c|c|c|c|c|}
\hline & & & $\begin{array}{c}\text { Sum of } \\
\text { Squares }\end{array}$ & $\mathrm{df}$ & $\begin{array}{c}\text { Mean } \\
\text { Square }\end{array}$ & $F$ & Sig. \\
\hline \multirow{5}{*}{$\begin{array}{l}\text { ROA BPRS } \\
\text { * Suku } \\
\text { Bunga SBI }\end{array}$} & & (Combined) & 43.217 & 12 & 3.601 & 1.637 & .221 \\
\hline & Between & Linearity & 2.352 & 1 & 2.352 & 1.069 & .326 \\
\hline & Groups & Deviation from & 40.866 & 11 & 3.715 & 1.689 & .209 \\
\hline & Within $\mathrm{Gr}$ & & 22.000 & 10 & 2.200 & & \\
\hline & Total & & 65.217 & 22 & & & \\
\hline
\end{tabular}

Sumber: Hasil Olah SPSS 20

Berdasarkan nilai Signifikansi dalam tabel diatas dapat disimpulkan bahwa terdapat hubungan linear secara signifikan antara Suku Bunga SBI dengan ROA BPR Syariah dengan nilai signifikan 0,209 lebih besar dari 0,05.

\section{Uji Heterokedastisitas BPR Syariah}

Berikut ini adalah hasil uji heterokedastisitas pada BPR Syariah:

Tabel 8. Uji Heterokedastisitas BPR Syariah

$$
\text { Coefficients }^{\mathrm{a}}
$$

\begin{tabular}{|rl|r|r|r|r|r|}
\hline \multicolumn{2}{|l|}{ Model } & \multicolumn{2}{|c|}{ Unstandardized Coefficients } & \multicolumn{1}{|c|}{$\begin{array}{c}\text { Standardized } \\
\text { Coefficients }\end{array}$} & \multirow{2}{*}{ Sig. } \\
\cline { 3 - 5 } & \multicolumn{1}{|c|}{$\mathrm{B}$} & Std. Error & \multicolumn{1}{c|}{ Beta } & & \\
\hline \multirow{2}{*}{1} & (Constant) & 2.451 & 2.174 & & 1.127 & .272 \\
& Suku Bunga SBI & -.193 & .349 & -.120 & -.553 & .586 \\
\hline
\end{tabular}

a. Dependent Variable: Abs_RES

Sumber: Hasil Olah SPSS 20

Hasil uji heteroskedastisitas dilakukan dengan Uji Glejser. Berdasarkan tabel diatas diperoleh Suku Bunga SBI nilai Sig sebesar 0,586 diatas 0,05 sehingga dapat disimpulkan bahwa tidak terjadi gejala heteroskedastisitas dalam model regresi ini.

\section{Hasil Uji Hipotesis (Uji T)}

Berikut ini adalah hasil uji hipotesis $\mathrm{H} 1$ dan $\mathrm{H} 2$ untuk penelitian ini: 
Tabel 8. Uji Hipotesis 1 dan Hipotesis 2

Coefficients $^{\mathrm{a}}$

\begin{tabular}{|ll|r|r|}
\hline Model & \multicolumn{1}{c|}{$\mathrm{t}$} & \multicolumn{1}{c|}{ Sig. } \\
\hline \multirow{2}{*}{1} & (Constant) & 1.512 & .142 \\
& Suku Bunga SBI & -.268 & .791 \\
\hline
\end{tabular}

a. Dependent Variable: ROA_BPR

\begin{tabular}{|ll|r|r|}
\hline \multicolumn{4}{|c|}{ Coefficients $^{\mathrm{a}}$} \\
\hline Model & & \multicolumn{1}{c|}{$\mathrm{t}$} & \multicolumn{1}{c|}{ Sig. } \\
\hline \multirow{2}{*}{1} & (Constant) & -.481 & .636 \\
& Suku Bunga SBI & .886 & .385 \\
\hline
\end{tabular}

a. Dependent Variable: ROA BPRS

Sumber: Hasil Olah SPSS 20

H1 : Ada pengaruh Suku Bunga SBI terhadap Profitabilitas (ROA) pada BPR Konvensional Di Kota Batam.

Berdasarkan hasil uji t di atas terlihat bahwa nilai signifikansi (Sig) 0,791 $<0,05$, maka dapat disimpulkan bahwa Ho diterima dan Ha ditolak, yang artinya "Suku Bunga SBI tidak berpengaruh terhadap Profitabilitas (ROA) pada BPR Konvensional Di Kota Batam".

Hasil penelitian ini berbeda dengan yang dilakukan oleh (Wardana, Setiawina, \& Budiasa, 2016) pada objek Bank Perkreditan Rakyat di Provinsi Bali. Hasil penelitian tersebut menunjukkan bahwa Policy Moneter SBI berpengaruh positif tidak signifikan secara langsung terhadap ROA Bank Perkreditan Rakyat di Provinsi Bali. Ternyata kebijakan moneter SBI memberi dampak positif terhadap pertumbuhan ROA pada Bank Perkreditan Rakyat di Propinsi Bali, sehingga Bank Sentral sebaiknya memberikan perhatian sungguh-sungguh dalam pengambilan kebijakan sehingga Bank Perkreditan Rakyat dapat melanjutkan keberlangsungannya.

Tetapi hasil penelitian ini sejalan dengan yang dilakukan oleh (Puspitasari, 2009) pada objek Bank Devisa di Indonesia Perioda 2003-2007. Hasil penelitian tersebut menunjukkan bahwa bahwa kenaikan Suku Bunga SBI tidak mempengaruhi besarnya Return on Asset (ROA).

Dengan melihat hasil yang diperoleh dalam penelitian ini maka dapat disimpulkan bahwa kenaikan dan penurunan Suku Bunga SBI yang dikeluarkan Bank Sentral tidak memberi dampak siginifkan terhadap kinerja Profitabilitas (ROA) BPR Konvensional yang ada di Kota Batam. Artinya perlu kajian lebih dalam lagi untuk mencari variabel-variabel lain yang lebih dominan mempengaruhi kinerja Profitabilitas (ROA) BPR Konvensional yang ada di Kota Batam.

H2 : Ada pengaruh Suku Bunga SBI terhadap Profitabilitas (ROA) pada BPR Syariah Di Kota Batam.

Berdasarkan hasil uji t di atas terlihat bahwa nilai signifikansi (Sig) $0,385<$ 0,05, maka dapat disimpulkan bahwa Ho diterima dan Ha ditolak, yang artinya "Suku Bunga SBI tidak berpengaruh terhadap Profitabilitas (ROA) pada BPR Syariah Di Kota Batam".

Hasil penelitian ini berbeda dengan yang dilakukan oleh (Wardana et al., 2016) pada objek Bank Perkreditan Rakyat di Provinsi Bali. Penelitian tersebut menunjukkan SBI berpengaruh positif tidak signifikan secara langsung terhadap ROA. Oleh karena kebijakan moneter SBI memberi dampak positif terhadap pertumbuhan ROA pada Bank Perkreditan Rakyat di Propinsi Bali, maka Bank Sentral sebaiknya memberikan perhatian sungguhsungguh dalam pengambilan kebijakan sehingga Bank Perkreditan Rakyat dapat melanjutkan keberlangsungannya.

Tetapi penelitian ini hampir sama dengan yang dilakukan oleh (Edhi Satriyo Wibowo, 2013) pada objek Bank Umum Syariah (BUS), dimana penelitian tersebut menggunakan variabel Suku Bunga. Hasil penelitian tersebut menunjukkan bahwa suku bunga tidak memiliki pengaruh yang signifikan terhadap ROA. Hasil penelitian tersebut menunjukkan bahwa hal ini disebabkan nasabah bank syariah nampaknya merupakan nasabah yang relatif loyal terhadap bank syariah. 
Dengan melihat hasil yang diperoleh dalam penelitian ini maka dapat disimpulkan bahwa kenaikan dan penurunan Suku Bunga SBI yang dikeluarkan Bank Sentral tidak memberi dampak siginifkan terhadap kinerja Profitabilitas (ROA) BPR Syariah yang ada di Kota Batam. Dan untuk itu perlu kajian lebih dalam lagi untuk mencari variabel-variabel lain yang lebih dominan mempengaruhi kinerja Profitabilitas (ROA) BPR Syariah yang ada di Kota Batam.

\section{Hasil Uji Hipotesis (Uji Beda t-tes)}

Sedangkan uji beda akan dijelaskan pada uraian berikut ini:

Tabel 8. Statistik Deskriptif

Group Statistics

\begin{tabular}{|l|l|r|r|r|r|}
\hline & $\begin{array}{l}\text { BPR Konvensional } \\
\text { dan Syariah }\end{array}$ & N & Mean & Std. Deviation & \multicolumn{1}{|c|}{$\begin{array}{c}\text { Std. Error } \\
\text { Mean }\end{array}$} \\
\hline $\begin{array}{l}\text { ROA BPR } \\
\begin{array}{l}\text { Konvensional } \\
\text { dan Syariah }\end{array}\end{array}$ & BPR Konvensional & 28 & 3.07 & 1.412 & .267 \\
\hline
\end{tabular}

Sumber: Hasil Olah SPSS 20

Dari tabel di atas dapat dijelaskan bahwa $\mathrm{N}$ adalah jumlah data yang diolah dan Mean adalah nilai rata-rata. Data BPR Konvensional yang dianalisis yaitu sebanyak 28 dan BPR Syariah sebanyak 23. Nilai Mean pada BPR Konvensional sebesar 3,07 sedangkan Mean pada BPR Syariah sebesar 1,35. Hal ini berarti bahwa selama periode 2015-2018 secara umum kinerja ROA pada BPR Konvensional lebih baik dibandingkan dengan kinerja ROA pada BPR Syariah di Kota Batam $(3,07>1,35)$.

Setelah dilakukan uji diatas selanjutnya adalah melakukan uji hipotesis Uji beda t-test. Uji beda t-test digunakan untuk menentukan apakah dua sample yang tidak berhubungan memiliki nilai rata-rata yang berbeda. Uji beda t-test dilakukan dengan cara membandingkan perbedaan antara dua dua nilai rata-rata dengan standar error dari perbedaan rata-rata sample. Untuk mengetahui apakah varians populasi identik ataukah tidak dengan ketentuan jika probabilitas > 0.05 , maka H0 tidak dapat ditolak jadi variance sama dan jika probabilitas $<0.05$, maka $\mathrm{H} 0$ ditolak jadi variance berbeda. Berikut ini adalah hasil ujinya:

Tabel 9. Hasil Uji Beda T-Test

Independent Samples Test

\begin{tabular}{|c|c|c|c|c|c|c|c|c|}
\hline & \multicolumn{2}{|c|}{$\begin{array}{c}\text { Levene's Test for } \\
\text { Equality of Variances }\end{array}$} & \multicolumn{5}{|c|}{ t-test for Equality of Means } \\
\hline & & \multirow[t]{2}{*}{$\mathrm{F}$} & \multirow[t]{2}{*}{ Sig. } & \multirow[t]{2}{*}{$\bar{T}$} & \multirow[t]{2}{*}{$\mathrm{df}$} & \multirow[t]{2}{*}{$\begin{array}{l}\text { Sig. (2- } \\
\text { tailed) }\end{array}$} & \multicolumn{2}{|c|}{$\begin{array}{l}95 \% \text { Confidence } \\
\text { Difference } \\
\text { Interval of the }\end{array}$} \\
\hline & & & & & & & Lower & Upper \\
\hline ROA BPR & $\begin{array}{l}\text { Equal variances } \\
\text { assumed }\end{array}$ & .077 & .783 & 3.929 & 49 & .000 & .842 & 2.605 \\
\hline dan Syariah & $\begin{array}{l}\text { Equal variances } \\
\text { not assumed }\end{array}$ & & & & 42.469 & .000 & .821 & 2.626 \\
\hline
\end{tabular}

Sumber: Hasil Olah SPSS 20

H3 : Ada perbedaan kinerja Profitabilitas (ROA) pada BPR Konvensional dan BPR Syariah.

Berdasarkan hasil uji beda t-test diatas terlihat bahwa nilai Sig. (2-tailed) sebesar 0,000 < 0,05 maka Ho ditolak dan Ha diterima yang artinya "ada perbedaan signifikan antara kinerja Profitabilitas (ROA) BPR Konvensional dan BPR Syariah di Kota Batam".

Hasil penelitian ini sejalan dengan yang dilakukan oleh (Hamidi, 2017) pada objek Bank Perkreditan Rakyat (BPR) Syariah dan Konvensional di Sumatera Barat. Hasil analisis penelitian tersebut menyimpulkan bahwa terdapat perbedaan kinerja dan penentu kinerja yang mendasar antara BPR Syariah dan Konvensional di Sumatera Barat. 
Berdasarkan statistik untuk konteks Sumatera Barat, BPR Konvensional memiliki kinerja keuangan (ROA, ROE, NIM) yang lebih unggul dibandingkan dengan BPR Syariah.

Hasil penelitian ini juga sejalan dengan yang dilakukan oleh (Arifuddin, 2012) pada objek BPR Sulawesi Selatan dan BPR skala Nasional (IRAMA--UKA). Hasil penelitian dengan menggunakan metode uji t statistik Independent-sample t-test untuk melihat perbandingan kinerja antar BPR yaitu BPR Sulawesi Selatan dan BPR skala Nasional (IRAMA-UKA) menunjukkan terdapat perbedaan signifikan ROA antar BPR Sulawesi Selatan dan BPR skala Nasional (IRAMA--UKA).

\section{SIMPULAN}

Berikut ini adalah simpulan hasil penelitian ini:

1. Berdasarkan hasil uji t diperoleh bahwa Suku Bunga SBI tidak berpengaruh terhadap Profitabilitas (ROA) pada BPR Konvensional Di Kota Batam dengan nilai signifikansi (Sig) $0,791<0,05$.

2. Berdasarkan hasil uji t diperoleh bahwa Suku Bunga SBI tidak berpengaruh terhadap Profitabilitas (ROA) pada BPR Syariah Di Kota Batam dengan nilai signifikansi (Sig) $0,385<0,05$.

3. Berdasarkan hasil uji beda t-test terlihat bahwa ada perbedaan kinerja Profitabilitas (ROA) pada BPR Konvensional dan BPR Syariah nilai Sig. (2-tailed) sebesar 0,000 $<0,05$. Selama periode 2015-2018 kinerja ROA pada BPR Konvensional lebih baik dibandingkan dengan kinerja ROA pada BPR Syariah di Kota Batam (Mean 3,07 > $1,35)$.

\section{SARAN}

Adapun saran yang diperlukan adalah sebagai berikut:

1. Peneliti lain sebaiknya menggunakan variabel independen lain selain dengan yang sudah digunakan dalam penelitian ini untuk dapat menjawab fenomena permasalahan kinerja Profitabilitas (ROA) BPR yang ada di Kota Batam.

2. BPR Syariah di Kota Batam harus meningkatkan kinerja Profitabilitasnya terutama nilai Return on Assets (ROA) karena terdapat perbedaan yang signifikan antara kinerja Profitabilitas (ROA) antara BPR Konvensional dan BPR Syariah di Kota Batam.

\section{DAFTAR PUSTAKA}

Arifuddin, A. (2012). Roa Bpr Dan Perbandingan Roa Antar Bprwilayah Sulawesi Selatan Dengan Bpr Wilayah Iramasuka.

Edhi Satriyo Wibowo, M. S. (2013). ANALISIS PENGARUH SUKU BUNGA, INFLASI, CAR, BOPO, NPF TERHADAP PROFITABILITAS BANK SYARIAH. DIPONEGORO JOURNAL OF MANAGEMENT. Retrieved from http://ejournals1.undip.ac.id/index.php/djom

Embu, W. S. (2018). BI pertahankan suku bunga acuan 4,25 persen, berlaku per 19 Februari. Retrieved from https://www.merdeka.com/uang/bi-pertahankan-suku-bunga-acuan-425persen-berlaku-per-19-februari.html

Ghozali, I. (2016). Aplikasi Analisis Multivarite Dengan Program IBM SPSS 23. (8th ed.). UNDIP Semarang.

Hamidi, M. (2017). Studi Komparasi Kinerja Bank Perkreditan Rakyat ( BPR ) Syariah dan Konvensional di Sumatera Barat. IQTISHADIA, Jurnal Kajian Ekonomi Dan Bisnis Islam, 10(1), 44-70. https://doi.org/http://dx.doi.org/10.21043/iqtishadia.v10i1.2318

Kasmir. (2015). Analisis Laporan Keuangan. Jakarta: Rajawali Pers.

Natalia, E. Y. (n.d.). Pengaruh Non Performing Loan dan Suku Bunga SBI Terhadap Profitabilitas Bank Perkreditan Rakyat di Kota Batam.

Natalia, E. Y. (2017). ANALISIS FAKTOR-FAKTOR YANG BERPENGARUH TERHADAP PERUBAHAN LABA PADA PERUSAHAAN PERBANKAN YANG TERDAFTAR DI 
BEI. Journal of Accounting \& Management Innovation, 1(2), 129-142.

OJK. (2018). Otoritas Jasa Keuangan. Retrieved from www.ojk.go.id

Puspitasari, D. (2009). ANALISIS PENGARUH CAR, NPL, PDN, NIM, BOPO, LDR, DAN SUKU BUNGA SBI TERHADAP ROA (Studi Pada Bank Devisa di Indonesia Perioda 2003-2007). TESIS, UNIVERSITAS DIPONEGORO, SEMARANG.

Putra, G. R. E. (2017). BI: Pertumbuhan KEPRI Paling Rendah Di Sumatera. Retrieved from https://finance.detik.com/berita-ekonomi-bisnis/d-3728761/bi-pertumbuhan-kepri-palingrendah-di-sumatera

Sugiarto. (2017). Metode Penelitian Bisnis. Yogyakarta: Andi.

Wardana, I. K., Setiawina, N. D., \& Budiasa, G. S. (2016). DAMPAK KEBIJAKAN SUKU BUNGA BANK INDONESIA TERHADAP RETURN ON ASSET BANK PERKREDITAN RAKYAT DI PROVINSI BALI. E-Jurnal Ekonomi Dan Bisnis Universitas Udayana, 6(ISSN : 2337-3067), 1785-1810.

Widiyanti, E. (2018). KUR Baru, Memperluas Akses Pembiayaan Bagi UMKM. Retrieved from http://kur.ekon.go.id/kur-baru-memperluas-akses-pembiayaan-bagi-umkm 